\title{
Exploring the Sustainability of Servant Leadership in a Covid-19 era: A Critical Analysis of the Nigerian Autocratic Entrepreneurial Ecosystem
}

\author{
Chimkwanum Okecha $^{1^{*}} \quad$ Mazen Joureih $^{2} \quad$ Johnson Oluwatobi Okeniyi $^{3}$ \\ 1.Leadership Core Department, African Leadership University, Pamplemousses, Mauritius \\ 2.School of Management, London School of Science and Technology, Birmingham, United Kingdom \\ 3.Business School, Roehampton University QA Birmingham, United Kingdom
}

\begin{abstract}
The rapid growth of Entrepreneurship in Nigeria since 1999 is indicative of the fact that it plays an integral role in the development of the Nigerian economy. New ventures, start up, innovation, systems thinking and human centered design now serve as pillars for the Nigerian entrepreneur in a competitive business world. However, inadequate attention is given as to how leadership can play a pivotal role in ensuring that these enterprises remain a going concern. This paper explores existing leadership practise in the Nigerian entrepreneurial ecosystem and investigates if servant leadership could ever be applicable. This paper recognizes the significance of bringing into the discourse the context of the culture dimension in identifying leadership possibilities in this Sub-Saharan growing economy. In critically evaluating the servant leadership theory, the study advocates that a new development in understanding this theory in relation to the Nigerian entrepreneur is to explore the Ubuntu leadership philosophy.
\end{abstract}

Keywords: Entrepreneur, Servant Leadership, Autocratic Leadership, Ubuntu, Nigerian Entrepreneur

DOI: $10.7176 / \mathrm{EJBM} / 12-26-01$

Publication date:September $30^{\text {th }} 2020$

\section{Introduction}

A typical definition of entrepreneurship is that it involves the process of starting a business venture (Allen, 2019). The key driver of this process is the entrepreneur who recognises a business opportunity within a market space and takes advantage of it, while embracing the risks associated with such venture (Gartner, 1998). There have been suggestions that a competitive business matrix should incorporate a connection between innovation and entrepreneurship (Schumpeter 2000, Scott 2006 and Malerba and McKelvey 2019).

Entrepreneurship been identified as critical factor to economic growth and sustainable development (Audretsch, 2006). The rapid growth of studies related to entrepreneurship is an indication of the significance of the phenomenon of entrepreneurship. However, there are limited studies that have investigated the concept of entrepreneurship in relation to leadership and culture. This is because most of the open literatures on entrepreneurship have mainly focused on what entrepreneurship is and its relative impact on society. Therefore, there is a need for systematic studies on what entrepreneurship is not and how effective should an entrepreneur lead giving into context cultural reality.

The purpose of this paper is to explore from a first-level perspective, the leadership practises of Nigerian entrepreneurs. It will also evaluate the role of culture in existing leadership styles and assess if there is an opportunity for the application of servant leadership.

The structure of the paper has adopted the following approach. The initial phase of the paper presents the method selected for the study. The next phase of the paper is the introduction of relevant literature that evolve around the key themes of the paper. The third phase is the review of empirical data derived from the research. Finally, the paper will present conclusions and suggestions for future research.

\subsection{Methodology}

This study is using quantitative research because it developed structured questions for participants to answer. These questions were distributed in the form of questionnaires. It is also quantitative in nature because data collected would be analysed using statistical methods as the SPSS to measure the level of relationships between dependent and independent variables. The use of quantitative research to this study would help to delimit personal bias as the process of quantitative data collection distanced the researchers from influencing the participants in any way.

This study deployed the use of the qualitative research strategy. This was done through design of semistructured interviews. These interviews were conducted with business leaders. The reason for adopting the qualitative research strategy was that this study was set to achieve more than measurable evidence obtained from quantitative research strategy. Since the inductive reasoning approach was engaged in this study, the qualitative research strategy was useful in providing more detail to the already gathered facts, as the researchers had the opportunity to observe behavioural responses. The qualitative research strategy was also employed in this study to 
enable participants have a greater sense of freedom to share their responses.

\section{Entrepreneurship: The Nigerian journey}

The drive towards indigenous entrepreneurship is established upon the premise that entrepreneurship would develop the Nigerian economy through job creation and redistribution of wealth. These benefits would come in the form of the utilization of local resources, the diffusion and divergence of economic activities and the utilisation of savings (Owualah, 1999; Inyang and Enuoh, 2009). An all-inclusive appraisal of the function of entrepreneurs in Nigeria reveal that they are making substantial contributions to national development. As at 2003, Aruwam (2006) pointed out that small and medium enterprises in Nigeria contribute 90 percent to total number of industrial establishments; 70 percent to total industrial employment and 10-15 percent to total industrial production. This corroborates the results of a previous study by Kuratko and Hodgett (2001) that small business enterprises employ 53 percent of the private workforce and accounted for 47 percent of sales and 51 percent of private sector gross domestic product GDP.

In this age of disruptive technology, systems thinking and human-centred design, innovation appears to be at the heart of entrepreneurship. This paper argues that while there seems to be a universal acceptance of how innovative an entrepreneur should be, little attention is given as to how the entrepreneur should lead. How many Nigerian entrepreneurs have their businesses last for more than 20 years? Would the average Nigerian entrepreneur prefer to use company funds for personal vacations and unnecessary personal projects? If he or she cannot lead self, how would intrapreneurs (that is, the employees) be effectively led.

\section{The Leadership Pendulum}

Leadership is a term that is associated with everyday life. It has been widely investigated from historical and contextual perspectives. According to Bass and Stogdill (1990), the study of history and philosophy over the centuries led to the development of principles of leadership. There have also been written philosophical evidences revealed over 5000 years ago through the Egyptian hieroglyphics that indicate that there has been a constant quest to understand the phenomenon of leadership. In Egypt as at that time, the hieroglyphics for leadership indicated directions as to how the leader (seshemu) should interact with the follower (shemsu).

According to Avery (2004), leadership is a subject of interest in complex civilisations. Likewise, Bass (2008) suggested that leadership is an investigated phenomenon in social sciences and an activity that is evident in both human and animal species. This suggestion agrees with the research previously carried out by De Waal (1996) who identified a display of leadership when studying chimpanzee behaviour in a captive colony in Arnhem Zoo, and observed that:

"a quarrel between Mama and Spin got out of hand and ended in fighting and biting. Numerous apes rushed up to the two warring females and joined in the fray. A huge knot of fighting, screaming apes rolled around in the sand, until Luit (the alpha male) leapt in literally beat them apart. He did not choose sides in the conflict, like others; instead anyone who continued to act received a blow from him". (p. 129).

Van Vugt (2006) stated that the Handbook of Leadership by Bass and Stogdill (1990) had acknowledged no fewer than 7,500 references to original articles on leadership. This view was extended by Yammarino (2013) who stated that leadership is one of the most widely researched and discussed topics in organisational sciences.

On the contrary, McCleskey (2014) disputed on the significance of a universal definition emphasizing that it was of no benefit to have a universal definition of leadership. Jackson, Sakuma and DeVol (2015) supports this view by stating that there are individual differences to the understanding of leadership. These differences are since factors as perceived identities, lived experiences, ethnicity, social class and even gender identities could influence the way people define leadership.

The term "Compassionate Autocrat" is not a common cliché in leadership study. This is because the term "Autocrat" does not appear to have positive suggestions. De Hoogh, Greer and Den Hartog (2015) described autocratic leadership as a leadership process in which decision making and is exemplified where the power to direct is centralised to an individual dominant leader.

Similarly, Bass and Bass (2009) described autocratic leadership as an approach in which the core qualities of the leader imply that all essential decisions are made by the leaders. Also, an autocratic leader's primary concern is the accomplishment of task and not follower motivation nor job satisfaction. A distinguishing element with autocratic leadership is the prevalence of social distance between the leader and the follower. While incentives and rewards mechanism could be used in other leadership styles to drive performance, the autocratic leader utilises the enforcement of threats and punishments. Adair (2009) described autocratic leaders as bureaucrats who have a "hire and fire" mentality and assumed that employees who work under autocratic leadership are most likely to experience feelings of insecurity and fear.

In the same way, Iqbal, Anwar and Haider (2015) observed that the autocratic leadership style is depicted by an "I tell" philosophy where leaders give clear directions to followers on what to do and create no opportunity for 
followers' contributions. This representation of the autocratic leader considers a leader who does not share his or her locus of control and decision-making function.

Critics such as Burns (2004) have questioned the autocratic leadership approach for its tendency to drive high turnover rates of followers, a tendency for employee to become less innovative, reduced follower motivation and morale, low job satisfaction and low organisational loyalty. Vugt et al., (2004) argued that within western democratic cultures, autocratic leadership does not provide a viable long-term solution to social dilemmas in open group settings. In an open group setting, an autocratic leadership style would make the leader unable to secure the welfare of the group in the long run which would lead to the exit of group members.

The above introduction of autocratic leadership is motivated by the need to take into consideration of the fact that the leadership style in Nigeria is predominantly autocratic in nature. If this is the case, how can servant leadership be applicable? What is servant leadership?

\subsection{The Leader as Servant}

The origin of the term "Servant Leadership" is accredited to Greenleaf who in 1970 published an essay called, "The servant as leader", after his review of a novel, 'Journey to the East' by Herman Hesse in 1960. According to Spears (1996), the interpretation of Greenleaf's understanding of the novel led to the formulation of an ideology that a great leader must firstly become a servant and get the experience as the servant, which is central to his/her greatness. Moreover, Spears (1996) described Journey to the East as a novel that depicted a collection of travellers on a mission to achieve spiritual needs. On their voyage, these travellers had a servant by the name of Leo who supported them through acts of service and provided direction when needed in the course of the journey.

However, at some point in the journey, Leo goes missing and his importance is only most realised at that point, for the sojourners needed him to complete their journey. He was needed because of his awareness of their final destination. After years of searching, the narrator encounters Leo who takes him into the religious order (the essence of their quest). Eventually, the narrator is shocked to realise that the servant Leo is actually the Head of the spiritual order, its guiding spirit and a gallant leader. According to Dwyer (2016), Greenleaf's idea of servant leadership has ignited the scope of leadership researchers to view leadership not only from the standpoint of the individual who leads but also from the follower who is empowered by the servant leader.

Several authors have attempted to define servant leadership after Greenleaf's (1977) famous definition of servant leadership as follows:

"The Servant-Leader is servant first....It begins with a natural feeling that one wants to serve first. Then conscious choice brings one to aspire to lead...The best test, and difficult to administer is this: Do those served grow as persons? Do they, while being served, become healthier, wiser, freer, more autonomous, and more likely themselves to become servants? And, what is the effect on the least privileged in the society? Will they benefit, or at least not further be harmed?" (p. 4).

Greenleaf (1977) further proposed that Servant Leadership is a leadership process in which there is a genuine concern of the leader towards the follower. This concern, therefore, brings about serving and leading the followers at the same time. In Greenleaf's (1977) investigation of the nature of legitimate power and greatness, he pointed out that Servant Leadership should be observed beyond its application as a management technique but also a way of life which commences with "the natural feeling that one wants to serve, to serve first" (pp. 13-14).

In the same way, in viewing servant leadership as a way of life, Graham (1991) argued that servant leadership involves serving multiple stakeholders which included society. While expanding the scope of beneficiaries to servant leadership practice, he emphasised that the way of life of the servant leader is to ensure that the followers' highest priority needs are met. However, further perspectives on what servant leadership is have emerged in recent years.

According to Spears (1996), Servant Leadership can be defined as a new leadership model that places serving others as dominant priority. This view is supported by Patterson (2003) who argued that Servant Leadership is an emergent leadership style that has high emphasis on service to followers, a holistic approach to work and one that upholds a sense of alliance and participation in decision-making processes.

Similarly, Luthans and Avolio (2003) described the leader who practices servant leadership as a servantleader and defined servant leadership as the practise in which the servant-leader builds opportunities for followers to develop within the organisation. They go further to argue that the servant-leader is one who leads not because of the need for power but the need to serve.

Having provided different definitions of servant leadership, it is important to identify what the characteristics of servant leadership are. Spears (1995) extended the work of Greenleaf by suggesting 10 characteristics of a servant leader. They are: Listening, Empathy, Emotional Healing, Persuasion, Awareness, Foresight, Conceptualization, Stewardship, Growth and Community Building. 


\subsection{The Culture Dimension}

Exploring the phenomenon of leadership in the Nigerian entrepreneurship space, whether it is autocratic, or servant leadership would not be satisfactory without bringing into context the culture dimension. Having reviewed over 150 definitions of culture from diverse disciplines, Kroeber and Kluckhohn (1952, p. 181).) stated:

"Culture consists of patterns, explicit and implicit, of and for behaviour acquired and transmitted by symbols, constituting the distinctive achievements of human groups, including their embodiment in artefacts; the essential core of culture consists of traditional (i.e. historically derived and selected) ideas and especially their attached values; culture systems may, on the one hand, be considered as products of action, on the other, as elements of further action".

Since this traditional definition of culture was articulated, many scholars have given their perspectives on culture. For example, Hampden-Turner and Trompenaars (1993) in their book, the Seven Cultures of Capitalism described culture as been relative to the values of a given society. They also scrutinised the notion of culture by bringing into perspective, its association with organisational behaviour and management practice. Similarly, in determining the relativity of culture to organisational practices and theories, Hofstede (1991, p. 48), asserted that culture involves "the collective mental programming which differentiates members of one group or society from those of another".

Moreover, House et al., (2004) observed that there is minimal debate on the idea that individuals live in a multicultural world, and that this fact should be paid attention to by leaders in organisations. He stated that it is antithetical the effective understanding of leadership to ignore the significance of culture. Also, Muchiri (2011) pointed out that not many scholars have sought to use the African leadership models as Ubuntu in exploring leadership practices in western contexts. This he argued, reflects the over reliance of westernised perspectives of management as a representation of societal expectations within a universal framework.

Ever since the 1980s, research on the significance of the importance of managing across cultures has been explored. However, Branine (2011) identified the influx of multinational companies, the rise in international competition, regional economic integrations, western management education, political and cultural influences and reforms in developing countries as significant drivers that help explain leadership as it relates to the culture dimension. Also, in alignment with the evolving scope of culture, it is being studied in its relation to leadership and management practices across cultures. To bring about clarity on the fundamental backgrounds of culture and leadership, the next section would review two of Hofstede's national cultural dimensions and the GLOBE cultural dimensions.

3.2.1 Power Distance: Hofstede (1983, p. 51) claimed that the research work of Mulder 1976 and 1977 had inspired his conceptualising of the term "power distance". Hofstede (1984, p. 390) defined power distance as a cultural characteristic which explains the degree to which the less powerful person in a given society accepts inequality in power as normal. According to Browaeys and Price (2008), a culture with high power distance would be represented by effective managers who are compassionate autocrats and unequivocally task focused. These managers are usually inaccessible and benefit from the privileges of power accorded to them. In a high power distance culture structure, subordinates are totally dependent on their leaders and most times receive the blame.

In comparison with low power distance cultures, Branine (2011) emphasises that leadership here is more concerned about competency and achievement than the pursuit of power and status. He also highlights that high level of employee participation is allowed in low power distance cultures in order to accomplish tasks and organisational objectives. The GLOBE study revealed that Nigeria had a mean score of 5.80 and ranked $2^{\text {nd }}$ in the power distance table. This score clearly classifies Nigeria as a society where power distance is highly prominent and indicates the existence of high power structures. In addition, other African countries such as Morocco $>5.80$, Zambia $>5.31$, and South Africa $>5.16$ show a high power distance.

3.2.2 Individualism versus Collectivism: According to Hofstede (2006), Individualism refers to groups or societies which reflect loose ties among individuals. In other words, each individual is focused on looking after himself or herself or immediate family, and no one else. Collectivism on the other hand, signifies societies that have original foundations which promote strong attachments to each other. Cultures that lay more emphasis on relationships built as compared to the task performed could be seen as collectivist cultures.

Browaeys and Price (2008) argued that in an organisation where there is collectivistic culture, the focus would be on the collective achievement of the team and not the accomplishment of individual objectives. Based on the GLOBE rankings, in relation to the societal In-group collectivism practices, it can be seen that Nigeria ranked $22^{\text {nd }}$ with a mean score of 5.55. This result indicates a greater collectivism in Nigeria. Also, the more a society is characterised by Institutional Collectivism practices, the more likely it is characterised by Assertiveness and Power Distance practices. Within this context, Hofstede's studies represent Nigeria as a society with a communal living pattern in which individuals have stronger feelings and a sense of obligation towards the interest of immediate and extended family members and members of social and religious groups they belong to.

Haffar et al., (2016) conducted an exploratory study of Nigerian and British consumers in relation to the influence of national culture on consumer buying behaviour and argued that culture and consumer behaviour 
provide an understanding of the residual threads of people that have become ingrained in their being, regardless of their exposure to other cultures. Their results showed that Nigerians are by nature collectivists and are more inclined to put group interests over personal interests.

\section{Ubuntu and Servant Leadership Matrix}

According to Mangaliso (2001, p. 24)

"Ubuntu can be defined as humaneness - a pervasive spirit of caring and community, harmony and hospitality, respect and responsiveness - that individuals and groups display for one another. Ubuntu is the foundation for the basic values that manifest themselves in the ways African people think and behave towards each other and everyone else they encounter".

Similarly, Karsten and Illa (2005) argued that Ubuntu represents an African perspective of the world which is fortified in its own person, society and culture and could be difficult to describe through a Westernised context. This view was strongly supported by Bekker (2007) who maintained that there exists an urgent need in Africa for a local, inventive and values-based leadership approach. He further suggested that the Ubuntu philosophy represents such approach, even as it helps to create better understanding of the relationship between leaders and followers by emphasising on harmony and continuity.

Although Van Binsbergen (2001), Newenham-Kahindi (2009) and Taylor (2014) neither attribute the coinage of the term "Ubuntu" nor the development of the theory to a particular individual, they agree that the terminology "Ubuntu" is derived from the Bantu Nguni languages of Xhosa, Zulu, Ndebele and Swati. They also stated that Ubuntu has become widespread in Sub-Saharan Africa and an ideology used to reflect Africa's values and culture. Newenham-Kahindi $(2007 ; 2009)$ argued that although Ubuntu is a prevalent African philosophy, it is termed differently across Africa. For instance, the people of Herero in Namibia refer to it as Avandu, the Sesotho tribe in Southern Africa utilise the word Batho, Swahili tribe in East Africa make use of the word Watu, and Bantu in Tanzania. In Central parts of Africa, words such as Kubuntu, Edubuntu and Ngumtu are used to refer to the Ubuntu philosophy; stressing the significance of togetherness.

In looking further at Ubuntu from a leadership perspective, Malunga (2009) stressed that the principle of Ubuntu requires the leader to become a role model. The leader's role is legitimised by his or her demonstration of key African values. These values include sincerity, solidarity, protection of each other's interest, empathy, compassion, honesty, respect for others and dignity. However, he explained that the abandonment of these traditional humanistic leadership value systems is closely linked to the development of leadership practices enforced in Africa through colonialist rule.

The outcomes of the practice of Ubuntu is a positive relationship to organisational development by serving as a strategic cultural integrator within an organisation (Dalitso, 2010). However, the big question is whether there is a relationship between servant leadership and Ubuntu?

A study was carried out by Brubaker (2013) to clarify the kind of relationships that existed between ServantLeadership, Ubuntu, and Leader Effectiveness in Rwanda. The participants of the inquiry consisted of employees working in the private sectors of the Rwandan economy. The findings of the study specified that from a Rwandan private sector context, servant-leadership had a significant and positive relationship to leader effectiveness. It also showed that servant-leadership and Ubuntu are two leadership models that are not significantly different in the strength of their relationships with leader effectiveness.

\section{Presentation of Findings}

The data analysis from 285 valid questionnaires are represented with the use of means, standard deviations and charts that are dependent upon a 5-point Likert scale. Findings from the interviews conducted with 14 male and 6 female business leaders are also presented. However, not all the business leaders are entrepreneurs. A few of them were intrapreneurs and top management team members (TMT's). They are referred to as Leads. Of all the 285 valid questionnaires obtained for data analysis, 182 were from male and 103 were from female respondents. This makes a representation of $64 \%$ males and $36 \%$ females. Also, the profiles of the respondents can be seen below. 
Table 1.1: Respondents Profiles

\begin{tabular}{|l|l|l|l|}
\hline Demographic Variables & Description & Frequency & Percentage (\%) \\
\hline Age & $18-25$ & 66 & 23.0 \\
(Years) & $26-35$ & 132 & 46.0 \\
& $36-45$ & 74 & 25.8 \\
& $46-55$ & 8 & 2.8 \\
& $56-65$ & 5 & 1.7 \\
\hline Work Experience & $1-11$ (months) & 6 & 1.0 \\
(Years) & $1-3$ & 44 & 15.8 \\
& $4-7$ & 200 & 69.7 \\
& 8 and above & 35 & 13.5 \\
\hline Staff Positions & Junior Level & 128 & 45.0 \\
& Middle Level & 121 & 42.6 \\
& Senior Level & 36 & 12.4 \\
\hline
\end{tabular}

Table 2.1: Perceptions of Gender on the Impact of Servant Leadership on Job Satisfaction

\begin{tabular}{|c|c|c|c|c|c|c|c|c|}
\hline Statements & $\begin{array}{l}\text { Mean } \\
\text { (M) }\end{array}$ & $\begin{array}{l}\text { Standard } \\
\text { Deviation } \\
\text { (S) }\end{array}$ & Gender & 1 & 2 & 3 & 4 & 5 \\
\hline $\begin{array}{l}\text { I have developed a close working relationship } \\
\text { with my manager }\end{array}$ & 3.42 & 0.952 & $\begin{array}{l}\mathrm{M} \\
\mathrm{F}\end{array}$ & $\begin{array}{l}4 \\
6\end{array}$ & $\begin{array}{l}19 \\
15\end{array}$ & $\begin{array}{l}68 \\
32\end{array}$ & $\begin{array}{l}70 \\
41\end{array}$ & $\begin{array}{l}22 \\
9\end{array}$ \\
\hline I feel left out of the team & 2.57 & 1.198 & $\begin{array}{l}\mathrm{M} \\
\mathrm{F}\end{array}$ & $\begin{array}{l}38 \\
24\end{array}$ & $\begin{array}{l}48 \\
42\end{array}$ & $\begin{array}{l}50 \\
8\end{array}$ & $\begin{array}{l}40 \\
19\end{array}$ & $\begin{array}{l}6 \\
10\end{array}$ \\
\hline $\begin{array}{l}\text { My manager acknowledges the team for a job } \\
\text { well done and not himself/herself }\end{array}$ & 2.84 & 1.103 & $\begin{array}{l}\mathrm{M} \\
\mathrm{F}\end{array}$ & $\begin{array}{l}24 \\
11\end{array}$ & $\begin{array}{l}51 \\
22\end{array}$ & $\begin{array}{l}63 \\
40\end{array}$ & $\begin{array}{l}29 \\
23\end{array}$ & $\begin{array}{l}15 \\
7\end{array}$ \\
\hline $\begin{array}{l}\text { I have been able to acquire new skillsets and } \\
\text { competencies because of the motivation I } \\
\text { received from my manager }\end{array}$ & 2.88 & 1.34 & $\begin{array}{l}\text { M } \\
F\end{array}$ & $\begin{array}{l}38 \\
15\end{array}$ & $\begin{array}{l}48 \\
30\end{array}$ & $\begin{array}{l}24 \\
17\end{array}$ & $\begin{array}{l}49 \\
27\end{array}$ & $\begin{array}{l}23 \\
14\end{array}$ \\
\hline $\begin{array}{l}\text { I get easily demotivated if I am confused of } \\
\text { what tasks I am to undertake }\end{array}$ & 3.82 & 0.906 & $\begin{array}{l}\mathrm{M} \\
\mathrm{F}\end{array}$ & $\begin{array}{l}1 \\
1\end{array}$ & $\begin{array}{l}24 \\
16\end{array}$ & $\begin{array}{l}9 \\
5\end{array}$ & $\begin{array}{l}115 \\
64\end{array}$ & $\begin{array}{l}33 \\
17 \\
\end{array}$ \\
\hline $\begin{array}{l}\text { I would not achieve optimum productivity if my } \\
\text { manager is not interested in my output }\end{array}$ & 3.52 & .944 & $\begin{array}{l}\mathrm{M} \\
\mathrm{F}\end{array}$ & $\begin{array}{l}5 \\
5\end{array}$ & $\begin{array}{l}22 \\
11\end{array}$ & $\begin{array}{l}36 \\
32\end{array}$ & $\begin{array}{l}101 \\
45\end{array}$ & $\begin{array}{l}18 \\
10\end{array}$ \\
\hline $\begin{array}{l}\text { I have a great chance to work, learn and grow } \\
\text { under my manager }\end{array}$ & 3.59 & 1.008 & $\begin{array}{l}\mathrm{M} \\
\mathrm{F}\end{array}$ & $\begin{array}{l}7 \\
3\end{array}$ & $\begin{array}{l}22 \\
10\end{array}$ & $\begin{array}{l}45 \\
25\end{array}$ & $\begin{array}{l}78 \\
47\end{array}$ & $\begin{array}{l}30 \\
18\end{array}$ \\
\hline $\begin{array}{l}\text { My manager makes me more innovative at my } \\
\text { job }\end{array}$ & 3.08 & 1.141 & $\begin{array}{l}\mathrm{M} \\
\mathrm{F}\end{array}$ & $\begin{array}{l}18 \\
17\end{array}$ & $\begin{array}{l}35 \\
13\end{array}$ & $\begin{array}{l}51 \\
30\end{array}$ & $\begin{array}{l}65 \\
35\end{array}$ & $\begin{array}{l}13 \\
8\end{array}$ \\
\hline I have work-life balance at my current job & 3.40 & 1.22 & $\begin{array}{l}\mathrm{M} \\
\mathrm{F}\end{array}$ & $\begin{array}{l}13 \\
5\end{array}$ & $\begin{array}{l}46 \\
21\end{array}$ & $\begin{array}{l}15 \\
24\end{array}$ & $\begin{array}{l}71 \\
34 \\
\end{array}$ & $\begin{array}{l}37 \\
19 \\
\end{array}$ \\
\hline $\begin{array}{l}\text { If I am satisfied with my work, it would } \\
\text { positively influence my output }\end{array}$ & 4.26 & 0.634 & $\begin{array}{l}\mathrm{M} \\
\mathrm{F}\end{array}$ & $\begin{array}{l}0 \\
0\end{array}$ & $\begin{array}{l}2 \\
2\end{array}$ & $\begin{array}{l}12 \\
6\end{array}$ & $\begin{array}{l}111 \\
53\end{array}$ & $\begin{array}{l}57 \\
42 \\
\end{array}$ \\
\hline
\end{tabular}

Table 2.1 above indicates that the statement "I have developed a close working relationship with my manager" generated a statistical mean of 3.42 and a standard deviation of 0.952 . It was also revealed that nearly one-third of male respondents $(35 \%)$ and a low number of female respondents $(18 \%)$ agreed to have developed close working relationships with their managers. Alternatively, a substantial number of male (24\%) and female (11\%) respondents gave neutral opinions on the nature of relationship they had established with their leaders. Surprisingly, a very insignificant number of respondents (male $8 \%$ and female $7 \%$ ) disagreed to having close working relationships with their managers. The contrast in these findings show that many of the respondents were uncertain as to whether they had developed a close working relationship with their leaders. It also shows that only an insubstantial number of females (18\%) claimed to have developed close working relationships with their leaders in a sector in which the leaders are predominantly male. However, this does not correlate with some of the interview responses which 5 business leaders said to have developed mutual working relationships with their employees. For example, when the Principal Consultant of a consulting company was asked to describe his level of relationship with his employees,

Lead 6 asserted:

I have created a work atmosphere where my employees feel at home and are highly motivated. I could only achieve this by developing a good work relationship with them, with very little boundaries.

The same question was asked to the Head of Sales of a Technology company, Lead 10 who confidently commented: 
I am very close to my team members and this is what I believe promotes team spirit within the company. My team members have the morale to deliver and they stand for each other, just as I stand for them.

However, when the Head of Human Resources Department of a hotel (Lead 13) that had won four hospitality awards between 2010-2016, for professionalism and innovation in the hospitality industry was asked the same question, he took some time to think and reluctantly stated:

I guess I would say that my leadership mantra has always been about "carry everyone along" and I ensure that this is done, not only by me by all the heads of units in this company. Also, I ensure that regardless of gender, each employee has the fair opportunity to grow their careers in this company.

In responding to the question of whether he felt his leadership affected his employees' morale and motivation in the company, and if yes, how? the CEO and Chairman of a notable HR outsourcing company (Lead 17) smiled and stated:

As a proactive company that we are, I lead in a way that my staff are happy to work and with their job roles. I consider this important, because if they are not happy at work, their productivity will drop. I have general meetings with the entire staff thrice every year to discuss openly how we are faring as a company and what we can do to improve.

Another response to the same question asked to Lead 17, led to the female Managing Director of a Technology company (Lead 19) making this interesting statement:

I pursue fairness and equity in the way I lead my employees, which I believe is a boost to their morale and motivation, as you asked. I intentionally make sure that we have an equal number of male and female managers who are competent and smart. I endeavour to see that employees do not feel left out because of their gender or do not sense they have the opportunity to be leaders in this company.

The statement "I feel left out of my team" generated a statistical mean of 2.57 and a standard deviation of 1.198. A low percentage of male (30\%) and female (23\%) disagreed to the statement, "I feel left out of the team". Similarly, a low number of male respondents $(16 \%)$ and an insignificant number of female respondents $(10 \%)$ agreed. These findings show a positive correlation of both sexes who agreed and were undecided as to feeling left out of the team. However, it is obvious that a higher number of female respondents disagreed to feeling left out of the team even though the leadership is male dominated. From Table 7.4.1, it is clearly seen that over $80 \%$ of the respondents said they got easily demotivated whenever they were unsure of their tasks. This implies that there were no significant differences between gender perceptions as both male and female respondents strongly agree that uncertainty of task function would drive them into a state of demotivation at work. These results corroborate with statements from Lead 4 and 7.

When Lead 4 was asked what whether his opinion of whether he felt employees were left out of the company, he happily replied:

In my experience as a leader of this company, I have come to learn that when employees are not clear of their job role and how it relates to the goals of the company, they lose their motivation. I ensure that my company has refresher programmes quarterly in a year, so that we are all on the same page. In this way, they are carried along.

Another interviewee, Lead 7 replied to the same question by stating:

I make sure that my employees are aware of where the company is going and do not feel left out. I encourage my supervisors to do the same by informing them of where we are, where we are headed and how they can contribute so we all get there. I would day my company is an open company.

A low minority of male $(26 \%)$ and female $(11 \%)$ respondents claimed that their team received acknowledgements from their managers for effectively accomplishing a task, rather than the manager claiming all the recognition. In contrast, $15 \%$ of male and $10 \%$ of female respondents said their managers did not display a habit of recognising the team for the successful completion of a task. Whereas, over one-fourth of the male $(22 \%)$ and one-seventh of the female (14\%) respondents were undecided as to whether their teams received acknowledgement from their leaders. This implies that both male and female respondents were of the notion that there was a major gap in team recognition from the managers. This extends further to reveal that managers appeared to receive most of the recognition for the effective achievement of a task, and not the team. Interestingly and in comparison, most of the interviewees' responses suggest that they drive team recognition, except Lead 3 who stated:

Whenever we successfully accomplish a notable task, I make sure the entire team is rewarded fairly. This is a way of the company saying, thank you for your hard work.

It was interesting to observe the passion with which Lead 7 stated:

My company has an ongoing reward scheme which helps to drive high performance within the company.

This is dependent however on what we can achieve within agreed timelines and the quality of work.

Moreover, the General Manger of Operations of a rapidly expanding telecommunications company Lead 12 stated:

I work with HR a lot to see that promotions are given to well deserving employees, whether the employee 
is a male or female. I see it as important that in my company, recognition of employees do not come only through words alone.

In response to the statement, "I have been able to acquire new skillsets and competencies because of the motivation I received from my manager", $25 \%$ of male and $14 \%$ of female respondents agreed, while $26 \%$ of male and $12 \%$ of female disagreed. In addition, $22 \%$ of male and $14 \%$ of female respondents remained undecided. Similarly, $37 \%$ of male and $22 \%$ of females agreed that they had a great chance to work, learn and grow under their manager. However, only $10 \%$ of male and $4 \%$ of females disagreed. This implies that there is a lack of skill development and employees' competences were not optimally improved upon. The consequence of this, suggests that employees do not feel their leaders provide the opportunity for them to learn and grow on their job activities. This finding disagrees with the results from $30 \%$ of the interviews.

For example, Lead 5 pointed out that,

My company has a skill gap programme handled by the HR department. What they do is to identify skills that employees do not have and provide adequate training for them within our company.

There was an energetic response from Lead 12 when stating:

There is no amount of money that is enough for developing staff that I can consider too much. I believe that when you train staff, they become better at their jobs and give back to the company what they have learnt. Staff development is key to my company's growth and there are some strategies we would not be able to implement except if employees do not develop certain skills.

Lead 15 showed so much interest in the question of describing the ways he as a leader was involved in developing employee skillsets and competencies. After getting up from his chair and pointing to a whiteboard and marker in his office, he replied:

I spend a lot of time working with my employees to identify areas where they lack required skills that would make them more effective in their job role. I start with my managers and supervisors. This is why I have this whiteboard in my office. I want my company to remain a learning company and one that focuses on developing the abilities of employees while they are on the job. My senior managers have whiteboards in their offices to, so they can help their team members too, in addition to the company wide- trainings we provide for them.

Another interviewee Lead 10 replied to the same question by saying:

As a technology company with a lot of competition, I make sure that my employees are well trained to be fit for the competition within our business space.

There was a short but concise response from the CEO of a telecommunications company, Lead 18 to the same question when he stated:

I always make efforts to see that my employees develop their skills and abilities through the support of the company.

The Managing Director of a consulting company Lead 20 gave this response to the same question by stating: At the beginning of every year, the HR unit sends me a training program for the company for the entire year. I review it with them and are clear of what the outcomes of these trainings would be. I know the importance of staff training and development and it has become an integral part of my company.

The respondents were asked to indicate their perception to this statement, "My manager makes me more innovative at my job." A slightly significant number of male $(27 \%)$ and female $(15 \%)$ respondents agreed. Similarly, a marginal number of male (19\%) and female (14\%) respondents disagreed. This clearly implies that the majority of the respondents hold the premise that their leaders have not effectively contributed to their innovative growth. Despite this, when asked on how they felt their leadership style influenced employees' job satisfaction, Lead 16 commented:

In this company, we have spent money on training and after a while, we noticed that after the training, some employees' leave for competitors or other companies where the skills they got would help them. I don't have a problem in staff leaving when they want to. It is inevitable, but I think it is a loss to the company if we have invested so much and get little. I spoke to HR and they developed in our training policy a contract agreement for certain training programmes in which the employee who has been trained cannot leave until after a certain period. I think employees also, have an individual responsibility to develop themselves by themselves and not always wait for the company.

In responding to this same question, Lead 9 asserted:

One thing I do for sure is to make sure that any employee that gets into this company leaves better than he or she came in. Being a consulting firm, we spend a lot of time and money in creating new ideas to meet the needs of our clients. For us to meet those needs, my staff need to be as creative as possible to keep up with current trends of our market industry. We provide the best trainings to make them effective and I am sure that gives them a good amount of job satisfaction. 
However, regardless of the commitment of business leaders towards training and staff development, a significant number of employees still do not support the notion that their leaders have improved their level of creativity and innovation in practise. Moreover, the results of this study as shown in Table 7.4.1 indicate that about one-third of male respondents $(32 \%)$ and one-quarter of female respondents $(25 \%)$ agreed to have work-life balance because of their current leader. Also, it is apparent from Table 7.4.1 that there was no increase of responses in support of having the chance to work, learn and grow in their organisations. This is because only $16 \%$ of male and $12 \%$ of females agreed. Though, further analysis of the results shows that nearly half of the male respondents (47\%) agreed to have developed new skillsets because of their managers. Surprisingly, a higher number of female respondents (64\%) agreed to this statement. On the contrary, only $29 \%$ of male and $29 \%$ of females agreed to their manager making them more innovative on their job. Similarly, when the issue of team cohesion based on managers' influence was asked, nearly half of the male respondents (48\%) and nearly two-thirds of the female respondents $(64 \%)$ agreed to feeling left out of their teams. Even though, a very significant majority of $92 \%$ of the respondents agree that job satisfaction has a positive effect on their work output, the results however suggest that certain elements as employee motivation, innovation, employee development, team cohesiveness, motivation and morale and work-life balance that contribute to job satisfaction have not been substantially met by the business leaders within the organisations where they work. Consequently, it provides evidence of an overwhelming need for job satisfaction as respondents believe that job satisfaction is a key determinant of their work output.

\begin{tabular}{|c|c|c|c|c|c|c|c|c|}
\hline & Statements & $\begin{array}{l}\text { Mean } \\
(\mathrm{M})\end{array}$ & $\begin{array}{l}\text { Standard } \\
\text { Deviation } \\
(\mathrm{S}) \\
\end{array}$ & $\begin{array}{l}\text { Strongly } \\
\text { Disagree } \\
(\%) \\
\end{array}$ & $\begin{array}{l}\text { Disagree } \\
(\%)\end{array}$ & $\begin{array}{l}\text { Undecided } \\
(\%)\end{array}$ & $\begin{array}{l}\text { Agree } \\
(\%)\end{array}$ & $\begin{array}{l}\text { Strongly } \\
\text { Agree } \\
(\%)\end{array}$ \\
\hline 1 & $\begin{array}{l}\text { I receive direction } \\
\text { from my manager on } \\
\text { how to achieve my } \\
\text { tasks }\end{array}$ & 3.47 & 1.012 & 4.6 & 9.5 & 35.8 & 34.7 & 15.4 \\
\hline 2 & $\begin{array}{l}\text { I receive required } \\
\text { resources from my } \\
\text { manager to enable me } \\
\text { to accomplish my tasks }\end{array}$ & 3.67 & 1.07 & 6.3 & 8.4 & 15.8 & 50.9 & 18.6 \\
\hline 3 & $\begin{array}{l}\text { I relate with my } \\
\text { manager as though } \\
\text { he/she were a family } \\
\text { member }\end{array}$ & 3.7 & 1.037 & 5.6 & 8.1 & 15.1 & 53 & 18.2 \\
\hline 4 & $\begin{array}{l}\text { My manager sees } \\
\text { himself/herself as part } \\
\text { of the team }\end{array}$ & 3.81 & 0.956 & 3.2 & 7.7 & 14.7 & 53.7 & 20.7 \\
\hline 5 & $\begin{array}{l}\text { I receive full attention } \\
\text { to my problems from } \\
\text { my manager }\end{array}$ & 3.67 & 0.991 & 4.6 & 8.8 & 17.2 & 54 & 15.4 \\
\hline 6 & $\begin{array}{l}\text { My manager values } \\
\text { team contribution }\end{array}$ & 2.92 & 1.076 & 25.1 & 27.2 & 7.9 & 22.6 & 17.2 \\
\hline 7 & $\begin{array}{l}\text { My manager respects } \\
\text { me as a person }\end{array}$ & 3.74 & 0.943 & 2.5 & 11.2 & 12.3 & 57.9 & 16.1 \\
\hline 8 & $\begin{array}{l}\text { Fairness is promoted } \\
\text { by my manager }\end{array}$ & 3.62 & 1.077 & 5.3 & 11.6 & 17.9 & 46.7 & 18.6 \\
\hline 9 & $\begin{array}{lr}\text { My } & \text { manager's } \\
\text { decisions } & \text { are } \\
\text { dependent } & \text { upon the } \\
\text { collective agreement } \\
\text { of the unit/department }\end{array}$ & 2.86 & 1.065 & 25.9 & 34.4 & 19.3 & 7.8 & 12.6 \\
\hline 10 & $\begin{array}{l}\text { My manager respects } \\
\text { the elderly within my } \\
\text { unit/department }\end{array}$ & 3.62 & 1.133 & 6 & 11.9 & 18.2 & 41.4 & 22.5 \\
\hline
\end{tabular}

\section{Table 3.1 Respondents Perception to Ubuntu and Servant Leadership}

Table 3.1 above reveals through the calculated statistical mean of 3.47>, and a Standard Deviation (SD) of 1.012 that approximately half $(50.1 \%)$ of the respondents agree that they receive direction from their managers on how to achieve their tasks. However, it is important to report that a significant number of respondents $(35.8 \%)$ provided neutral responses as to whether they felt their managers provided direction on how they can accomplish their tasks. Also, $14.1 \%$ of the respondents stated that they did not receive direction from their managers as it 
relates to their tasks. These findings do not significantly confirm those of the interviewees, of which 14 out of 20 of the business leaders interviewed frequently used the term "direction" to illustrate their leadership style.

For example, Lead 3 said:

I am far ahead of my team so that I can clearly set the goals they need to execute, and at the same time show them the direction they should follow.

Similarly, Lead 14 asserted:

For me, I lead by showing the way and I spend a lot of time showing my team members the direction the company is headed and how best the way they work can help us reach our objectives. I see myself as a leader of vision and this is what I think enables me provide direction to my team. It is frustrating when employees have no clear idea of what to do and where the company is going to. I bridge that gap and bring in clarity to the day to day activities in my company.

The table 3.1 also highlights through a derived statistical mean of 3.67> and a standard deviation of 1.07 that the respondents received the required resources from their managers to enable them accomplish their tasks. It shows that a very significant number of the respondents $(69.5 \%)$ agree to be beneficiaries of necessary support from their managers to achieve their tasks. This correlates with the premise by the CEO of an Estate and Property company, Lead 9 who stated:

As the CEO of this company, I make sure that employees are given all the required support they need from their heads of units because I cannot demand high performance from my employees, when a workable framework has not been put in place to enhance their work output. As much as I require efficiency from my employees, I always hold their heads of units and supervisors accountable first, because these employees cannot deliver what they have been trained for.

Furthermore, Table 3.1 reveals through a calculated mean of 3.7> and a standard deviation of 1.03 that a highly significant number of the respondents (71.2\%) attributed the kind of relationship they had with their managers as that of a family member. This demonstrates the collectivist nature of the organisation, even though a low number of respondents $(13.7 \%)$ disagreed to relating with their managers as though he or she were a family member. Furthermore, the majority of the respondents $(74.4 \%)$ felt their managers saw themselves as part of the team. This theme generated a statistical mean of 3.81 $>$ and a standard deviation of 0.956 . It can be illustrated from the table through a mean of 3.67> and a standard deviation of 0.991 that a significant number of respondents (69.4\%) agreed to receiving full attention from their managers regarding their problems. Also, a calculated statistical mean of $2.92<$ and an Sd of 1.076 strongly indicates that a large minority of respondents (39.8\%) agreed that their managers valued team contribution, while more than half of the respondents $(52.3 \%)$ confirmed that their managers did not value team contribution. However, this does not corroborate with the statements made by most of the leaders. For example, Lead 16 describes the culture of his organisation by asserting:

The culture of this organisation is such that we all work together as a family to achieve our common objective. My leadership style shows itself as I for one see myself as a builder of people. I bring my teams to work together and create brilliant ideas that would help our company grow at the centre of a lot of business competition. I like my employees to think for themselves and share ideas. This company has a culture of great team spirit and dedication to duty.

The theme of respect within culture was revealed through a calculated statistical mean of 3.74 $>$ and a standard deviation of 0.943 which indicates that the majority of the respondents $(74 \%)$ felt their managers respected them individually. Remarkably, the calculated statistical mean of $2.86<$ and a standard deviation of 1.056 proves that a high majority of the respondents $(60.3 \%)$ claimed that the decisions made by their managers were not dependent upon the collective agreement of the team. This indicates the lack of delegation in decision making processes from leaders to followers.

\subsection{Discussion}

It is now evident from the empirical findings that Nigerian entrepreneurs promote a culture in which employees do not freely make their personal suggestions to their leaders. It also revealed that the objectives of the team supersede the personal goals of the individual employees. In addition, it showed that most leaders do not take full responsibility for the actions of their employees and that majority of the employees were not of the perception that their leaders were genuinely interested in the personal goals of their employees.

The complexity of these findings only reinvigorates the proposition that the way to identify the existence or non-existence of servant leadership is to first investigate the kind of culture that is dominant in Nigerian companies. Even though autocratic leadership is the central leadership approach practised by Nigerian entrepreneurs, this paper has also indicated some positive feedback from the respondents regarding their leaders. If existing status quo in the practise is autocratic leadership is going to evolve to the adoption of servant leadership, the following questions need to be answered:

1. Considering the cultural reality in Nigeria, is autocratic leadership the most sustainable and realistic 
leadership approach?

2. Can Nigerian entrepreneurs be re-oriented towards a mindset of servant leadership through the practise of the Ubuntu philosophy?

3. Are Nigerian entrepreneurs ready for a disruption in current leadership practises to the adoption of servant leadership?

These questions call the need for further investigation. However, a few recommendations would be introduced in the concluding section of this paper.

\section{Conclusion}

The literature is progressively identifying the importance of entrepreneurship to the development of the Nigerian economy. It goes beyond the economic impact of entrepreneurship to the sustainability of entrepreneurship through leadership. This extension involved an analysis of the autocratic leadership style which is current practise, and servant leadership.

This article found that a possible explanation for the less prevalent practice of fundamental servant leadership characteristics ascribes to the conformist culture that is predominantly driven by Nigerian entrepreneurs. In addition, findings from this investigation revealed that Nigerian entrepreneurs tend to be more focused on selfinterest than the well-being of their employees.

When culture was brought into perspectives, it was revealed that Nigerian entrepreneurs drive a culture of compliance in their leadership which is demonstrated by their use of authority rather than persuasion. As such, the outcome of this is that it constructs a matrix of enforcement rather than involvement.

This culture dimension is represented by what I call the "Leader is never wrong syndrome". This term signifies a culture in which employees tend to always agree with business leaders. The outcome of this practice is a workplace where Nigerian entrepreneurs face no constructive criticism. It has become very evident from this study that leadership practice exhibited by Nigerian entrepreneurs has a lot of resemblance to the cultural elements of the past in which Colonialism imposed authority.

However, this paper found that such behaviour does not align with the core traditional African value system of Ubuntu which is symbolised by a shared value system, care, and interconnectedness. It also does not reflect African cultural value in which the leader represents the head of the family or tribe and the individual who does not eat until everyone in the family has eaten. Therefore, this paradigm shift is a continuation of colonial influence of administration rather Africa's philosophy of leadership centred on humanistic values. The implication of this, is that what was always known as Africa's indigenous leadership philosophy "Ubuntu" has lost its core strength in current leadership practice. Therefore, this philosophy of humanness that integrates Africa's culture and into a communal enterprise has been lost to a culture driven by a hierarchy of command and control mechanisms. Therefore, to introduce Servant Leadership, it is pertinent to revisit Ubuntu. The argument therefore is that for servant leadership to be effective, it must be activated in way that is culturally acceptable and realistic.

\section{References}

Adair, J. (2009). Not bosses but leaders: How to lead the way to success. London: Kogan Page Publishers.

Allen, J.P., 2019. Digital Entrepreneurship. Routledge.

Aruwa, S.A.S. (2006). Entrepreneurial development, small and medium enterprises. Kaduna: Entrepreneurship Academy Publishing

Audretsch, D.B., 2006. Entrepreneurship, innovation and economic growth. Cheltenham: Edward Elgar.

Avery, G.C. (2004). Understanding leadership: Paradigms and cases. Thousand Oaks: Sage Publications.

Bass, B.M. (2008). The Bass handbook of leadership: Theory, research and managerial applications.

Bass, B.M. and Bass, R. (2009). The Bass handbook of leadership: Theory, research, and managerial applications. Simon and Schuster.

Bass, B.M. and Stogdill, R.M. (1990) Bass \& Stogdill's handbook of leadership: Theory, research, and managerial applications. Simon \& Schuster.

Bekker, C.J.2. (2007). Dreaming with open eyes: Reflections on leadership and spirituality. Regent University, School of Global Leadership and Entrepreneurship. Available at: http://www.regent.edu/acad/global/publications/working/Dreaming\%20with\%20Open\%20

Eyes\%20-\%20Reflections\%20on\%20Leadership\%20and\%20Spir ituality\%20-\%20Bekker\%202007.pdf (Accessed: 9 May 2016).

Branine, M. (2011). Managing across cultures: Concepts, policies and practices. London: Sage.

Browaeys, M. and Price, R. (2008). Understanding cross-cultural management. Harlow: Pearson Education.

Brubaker, T.A. (2013). Servant leadership, Ubuntu, and leader effectiveness in Rwanda. Emerging Leadership Journeys, 6(1), pp.95-131.

Burns, J.M., 2004. Transforming leadership: A new pursuit of happiness (Vol. 213). Grove Press.

Dalitso, S. (2010). "I Am Because We Are": Ubuntu as a Cultural Strategy for OD and Change in Sub -Saharan 
Africa. Organisational Development Journal, 28(4) pp.25-49.

De Hoogh, A.H., Greer, L.L., and Den Hartog, D.N. (2015). Diabolical dictators or capable commanders? An investigation of the differential effects of autocratic leadership on team performance. The Leadership Quarterly, 26(5), pp.687-701.

Dwyer, B. (2016). Cultivating Dialogue: A Central Imperative for the Study and Practice of Servant Leadership', SLTP Journal.

Gartner, W. B. (1988). Who Is an Entrepreneur? Is the Wrong Question. American Journal of Small Business 12(4), 11-32. Retrieved from http://business2.fiu.edu/1660397/www/Session\%202\%20Readings/Gartner 1988 All.pdf

Graham, J.W. (1991). Servant-leadership in organizations: Inspirational and moral. The Leadership Quarterly, 2(2), pp.105-119.

Greenleaf, R.K. (ed.) (1977). Servant leadership: A journey into the nature of legitimate power and greatness. New York: Paulist Press.

Haffar, M., Enongene, L.N., Hamdan, M., and Gbadamosi, G. (2016). The Influence of National Culture on Consumer Buying Behaviour: An Exploratory Study of Nigerian and British Consumers. World Academy of Science, Engineering and Technology, International Journal of Social, Behavioral, Educational, Economic, Business and Industrial Engineering, 10(8), pp.3040-3045.

Hampden-Turner, C.H., and Trompenaars, F. (1993). The seven cultures of capitalism. New York: Transworld Publishers Limited.

Hofstede, G. (1983). The cultural relativity of organizational practices and theories. Journal of International Business Studies, pp.75-89.

Hofstede, G. (2006). What did GLOBE really measure? Researchers' minds versus respondents' minds. Journal of International Business Studies, 37(6), pp.882-896.

Hofstede, G., (1991). Cultures and organizations. Intercultural cooperation and its importance for survival. Software of the mind. London: McGraw-Hill.

House, R.J., Hanges, P.J., Javidan, M., Dorfman, P.W. and Gupta, V. (2004). Culture, leadership, and organizations: The GLOBE study of 62 societies. Sage publications.

Inyang, B.J. and Enuoh, R.O., 2009. Entrepreneurial competencies: The missing links to successful entrepreneurship in Nigeria. International business research, 2(2), pp.62-71.

Iqbal, N., Anwar, S., and Haider, N. (2015). Effect of leadership style on employee performance. Arabian Journal of Business and Management Review, 5(5).

Jackson, S., Sakuma, S. and DeVol, P., 2015. The Complexity in Defining Leadership: How Gifted Students' Backgrounds Influence Their Understanding of Effective Leadership. NCSSS journal, 20(1) pp.40-46.

Karsten, L., and Illa, H. (2005). Ubuntu as a key African management concept: contextual background and practical insights for knowledge application. Journal of Managerial Psychology, 20(7), pp.607-620.

Kroeber, A.L. and Kluckhohn, C., (1952). Culture: A critical review of concepts and definitions. Papers. Peabody Museum of Archaeology \& Ethnology, Harvard University.

Kuratko, D. F. \& Hodgett, R. M. (2001). Entrepreneurship: A contemporary approach. New York: Harcourt Inc.

Luthans, F., \& Avolio, B. (2003). Authentic leadership development. In K. S. Cameron \& J. E. Dutton. Positive organizational scholarship: 241-254. San Francisco: Berrett-Koehler.

Malerba, F. and McKelvey, M., 2019. Knowledge-intensive innovative entrepreneurship. Foundations and Trends ${ }^{\circledR}$ in Entrepreneurship, 14(6), pp.555-681.

Malunga, C.W., (2009). Understanding Organizational Leadership through Ubuntu/by Chiku Malunga.

Mangaliso, M.P. (2001). Building competitive advantage from Ubuntu: Management lessons from South Africa. The Academy of Management Executive, 15(3), pp.23-33.

McCleskey, J.A., (2014). Situational, transformational, and transactional leadership and leadership development. Journal of Business Studies Quarterly, 5(4), p.117.

Muchiri, M.K. (2011). Leadership in context: A review and research agenda for sub-Saharan Africa. Journal of Occupational and Organizational Psychology, 84(3), pp. 440-452.

Newenham-Kahindi, A. (2007). The Impact of Global Business Models in a Developing Country: The Case of Human Resource Management in Two Multinational Banks Operating in Tanzania. Unpublished PhD Dissertation, TCD, University of Dublin, Dublin, Ireland.

Newenham-Kahindi, A. (2009). The Transfer of Ubuntu and Indaba Business Models Abroad A Case of South African Multinational Banks and Telecommunication Services in Tanzania. International Journal of Cross Cultural Management, 9(1), pp. 87-108.

Ofili, O.U., 2014. Challenges facing entrepreneurship in Nigeria. International Journal of Business and Management, 9(12), p.258.

Owualah, S.I. (1999). Entrepreneurship in small business firms. (1st Ed). Lagos: G-MAG Investment Ltd (Educational Publishers) 
Patterson, K.A. (2003) Servant leadership: A theoretical model. Doctoral dissertation, Regent University).

Schumpeter, J.A., 2000. Entrepreneurship as innovation. Entrepreneurship: The social science view, pp.51-75.

Scott, A.J., 2006. Entrepreneurship, innovation and industrial development: geography and the creative field revisited. Small business economics, 26(1), pp.1-24.

Spears, L. (1996). Reflections on Robert K. Greenleaf and servant-leadership. Leadership and Organization Development Journal, 17(7), pp.33-35.

Spears, L.C. (1995). Reflections on leadership: How Robert K. Greenleaf's theory of servant-leadership influenced today's top management thinkers. New York: John Wiley \& Sons.

Taylor, D.F. (2014). Defining Ubuntu for business ethics-A deontological approach. South African Journal of Philosophy, 33(3), pp.331-345.

Van Binsbergen, W.M., (2001). Ubuntu and the globalisation of Southern African thought and society. Quest, 15, p.53.

Van Vugt, M. (2006). Evolutionary origins of leadership and followership, Personality and social psychology review. Society for Personality and Social Psychology, 10(4), pp.354-371. doi: 10.1207/s15327957pspr1004_5.

Van Vugt, M., Jepson, S.F., Hart, C.M., and De Cremer, D. (2004). Autocratic leadership in social dilemmas: A threat to group stability. Journal of Experimental Social Psychology, 40(1), pp.1-13.

Yammarino, F. (2013). Leadership: Past, present, and future. Journal of Leadership and Organizational Studies, 20(2), pp.149-155

\section{Authors}

Dr Chimkwanum Okecha is a lecturer in Entrepreneurial Leadership at the African Leadership Campus in Mauritius. His research interests include Leadership, Grassroots Entrepreneurial Interventions, Cross-Cultural Management, Talent Development, Organisational Culture and Emotional Intelligence. Okecha holds a PhD in Business and Management (with specialization in Leadership) from Abertay University in Scotland as well as an MBA in Human Resource Management from the University of Wales. He is an Associate Fellow of Higher Education Academy in the United Kingdom. He combines his experience in the corporate industry with research and has presented a paper on Servant Leadership and Ubuntu at the prestigious IST conference in Gothenburg, Sweden.

Dr Mazen Joureih has a PhD in Business management from Cardiff Metropolitan University. Prior to this, he obtained MBA from the University of Wales as well as a PGD and BSc. His research interests focus upon the relationship between human resource management and organisational performance, and the full spectrum of human capital development. Currently, he is working as a visiting researcher with a research group at Cardiff Metropolitan University and a lecturer in International Marketing Management at LSST.

Dr Johnson O. Okeniyi holds a PhD in Business and Management from Abertay University, Dundee, Scotland, and an MSc in Project Management from Northumbria University, Newcastle, England, and a BSc. in Management from Central University, Accra, Ghana. He is an Associate Fellow of Higher Education Academy in the United Kingdom. His research developed the first model for a sustainable strategic alliance between local SMEs and MNCs in Ghana. He is an expert in the field of strategic alliances between SMEs and larger organizations, a lecturer and an entrepreneur. His research interests include Sustainable Partnership between SMEs and Large Organisations, Strategic Alliances, Project Management and Entrepreneurship. He is very passionate about making more entrepreneurs, especially from youths that deem themselves, thinkers. 